5. Савельев В.В. Регионализация как условие повышения эффективности культурной политики. Отриентиры культурной политики. М.: ГИВЦ, 2003. С.46-61.

6. Adorno T. W. Kultur und Vervaltug. Szoilogishe Schrifien I. Frankfurt a. M. 1972.

\title{
References
}

1. Senchenko, M.I.( 2004).The "cultural revolution" in Ukraine, or the management of degradation. K .: MAUP [in Ukrainian].

2. Strika, M. (1996).Ukrainian state and culture: an attempt to search for interaction on the background of world experience. State building, 11, 50-53 [in Ukrainian].

3. Sweet, D. (2008). National identity as a factor of national and international security. Political management, 2, 110-119 [in Ukrainian].

4. Ruban, Yu.G. (2009). Conceptual principles of humanitarian development of Ukraine: strategic priorities of state policy. Strategic Priorities: [sci. Analyst. every quarter Sb.], 3 (12) [in Ukrainian].

5. Cavelev, V.V . (2003). Regionalization as a condition for increasing the effectiveness of cultural policy. Cultural Policymakers. M .: GIVS, 46-61 [in Ukrainian].

6. Adorno, T. W. (1972). Kultur und Vervaltug. Szoilogishe Schrifien I. Frankfurt a. M. [in English].

Стаття надійшла до редакиії 19.11.2018 p.

УДК 008: 130.2 "19/20"

\author{
Айгістова Аміна Аскярівна, \\ здобувач Київського національного університету \\ культури і мистецтв \\ ORCID 0000-0002-7927-0454
}

\section{СХІД І ЗАХІД У ЗВУКООБРАЗАХ СВІТОВОЇ ГАРМОНІЇ: ДИХОТОМІЯ ТА ДУАЛІЗМ КУЛЬТУР}

Метою статті $є$ дослідження специфіки моделювання звукообразів світової гармонії у філософськокультурологічних аспектах репрезентації проблематики «Схід-Захід» у музичній культурі. Методологія. Застосовано сукупність методів та методологічних підходів культурологічного, текстологічного, компаративного, культур-герменевтичного аналізу. Наукова новизна. Проведене дослідження дозволило, 3 одного боку, увиразнити конкретні змістові та мовно-виражальні напрями репрезентації звукообразів культур східного та західного цивілізаційного типу, а з іншого боку, констатувати доцентрові тенденції інтерпретації мовно-інтонаційного образу світу - від дихотомії до дуалізму східної та західної культур крізь призму відображення звукообразу тиші як художньо-музичного уособлення світової гармонії. Висновки. Сучасні глобально-цивілізаційні виклики актуалізують проблематику діалогу східної ї західної культур (азійського та європейського, північно-американського ареалу). 3 одного боку, загострюються культурні протиріччя, а 3 іншого, - пришвидшуються потоки міжкультурної комунікації за лініями східно-західного партнерства. Ці процеси знаходять безпосереднє виявлення в європейській музичній культурі, де філософсько-культурологічна специфіка репрезентації діалогової вісі «Схід-Захід» знаходить відображення у звукообразах як «художньозмістових концептах», що віддзеркалюють вектори протиставлення, віддалення, наближення та дуалізму культур. Останнє, виражається у звукообразах тиші, моделювання яких відповідає світоглядній парадигмі східного та західного мислення, уособлюючи ідеальний звуковий образ світової гармонії, що в умовах постмодерної парадигми є точкою культурного зближення двох антиномних світів.

Ключові слова: Схід-Захід, діалог культур, дихотомія культур, дуалізм культур, художній образ, звукообраз, гармонія, світова гармонія, звуковий образ світу.

Айгистова Амина Аскяровна, соискатель Киевского национального университета культуры $u$
искусствв
Восток и Запад в звукообразах мировой гармонии: дихотомия и дуализм культур
Цель работы. Целью статьи является исследование специфики моделирования звукообразов мировой
гармонии в философско-культурологических аспектах репрезентации проблематики «Восток-Запад» в
музыкальной культуре. Методология. Применена совокупность методов и методологических подходов
культурологического, текстологического, компаративного, культур-герменевтического анализа. Научная
новизна. Проведенное исследование позволило, с одной стороны, подчеркнуть конкретные содержательные и
выразительно-языковые направления репрезентации звукообразов культур восточного и западного
цивилизационного типа, а сдругой стороны - констатировать центростремительные тенденции интерпретации
интонационно-языкового образа мира - от дихотомии куализму восточной и западной культур сквозь призму

(C) Айгістова А. А., 2019 
отражения звукообраза тишины как художественно-музыкального олицетворения мировой гармонии. Выводы. Современные глобально-цивилизационные вызовы актуализируют проблематику диалога восточной и западной культур (азиатского и европейского, североамериканского ареала). С одной стороны, обостряются культурные противоречия, а с другой - ускоряются потоки межкультурной коммуникации по линиям восточно-западного партнерства. Эти процессы находят непосредственное отражение в европейской музыкальной культуре, где философско-культурологическая специфика репрезентации диалоговой оси «Восток-Запад» воплощается в звукообразах как «художественно-смысловых концептах», которые отражают векторы противопоставления, отдаления, приближения и дуализма культур. Последнее выражается в звукообразах тишины, моделирование которых соответствует мировоззренческой парадигме восточного и западного мышления, олицетворяя идеальный звуковой образ мировой гармонии, что в условиях постмодернистской парадигмы является точкой культурного сближения двух антиномных миров.

Ключевые слова: Восток-Запад, диалог культур, дихотомия культур, дуализм культур, художественный образ, звукообраз, гармония, мировая гармония, звуковой образ мира.

\section{Aygistova Amina, applicant of the Kiev National University of Culture and Arts}

East and West in the sound images of world harmony: the dichotomy and dualism of cultures

Purpose of the article. The purpose of the article is to study the specifics of modeling sound images of world harmony in the philosophical and cultural aspects of the reflection of «East-West» problematic in musical culture. Methodology. The set of methods and methodological approaches of cultural, textological, comparative, culturalhermeneutical analysis was applied. Scientific novelty. This study allowed, on the one hand, to emphasize specific meaningful and intonation-expressive directions of representation of sound images of cultures of the eastern and western civilization type, and on the other hand, to state the centripetal tendencies of interpretation of the sound image of the world - from the dichotomy to the dualism of Eastern and Western cultures through the prism of the reflection of the sound image of silence as the artistic and musical embodiment of world harmony. Conclusions. Modern global civilization challenges actualize the problems of dialogue between Eastern and Western cultures (Asian and European, North American area). On the one hand, cultural contradictions are exacerbated, and on the other hand, the flow of intercultural communication along the lines of the East-West partnership is accelerating. These processes are directly reflected in European musical culture, where the philosophical and cultural specificity of the representation of the dialogue axis «East-West» is embodied in the sound images as "artistic and semantic concepts" that reflect the vectors of opposition, distancing, approximation and dualism of cultures. The latter is expressed in the sound images of silence, the modeling of which corresponds to the ideological paradigm of Eastern and Western thinking, personifying the ideal sound image of world harmony, which in the postmodern paradigm is a point of cultural convergence of two antinomous worlds.

Keywords: East-West, a dialogue of cultures, a dichotomy of cultures, a dualism of cultures, artistic image, sound image, harmony, world harmony, sound image of the world.

Актуальність теми дослідження. В сучасній гуманітаристиці проблематика діалогу культур є достатньо артикульованою у естетико-філософському та історико-культурологічному дискурсі, у тому числі на обширній емпірико-аналітичній базі компаративістських дослідницьких студій матеріальної та нематеріальної спадщини східної (азійської) та західної (європейської, північноамериканської) художньої культури. Водночас, питання паралелізму та культурних опозицій у діалоговому контексті моделювання звукообразів Сходу і Заходу в музиці залишаються практично поза увагою музичної культурології, що не заперечує актуальності самої теми дослідження, а скоріше зумовлено перебуванням даної інтегративної науки на стадії свого функціонально-категоріального становлення.

Аналіз останніх досліджень і публікацій. На разі процеси предметної, структурно-змістової конкретизації, як видається, неосяжного проблемного поля музичної культурології розгортаються на міждисциплінарному стику культурології, музикознавства, філософії та естетики «у справжній музикальній гармонійності нового дискурсу науки» $[4,131]$. Кожен 3 цих комплементарноінтелектуальних полюсів асимілює розмаїття культурних форм, що на думку Т. Гуменюк та С.Тишка, «створює "квітучу складність" загальної картини розвитку світу, місця і ролі в ньому людини, надає змогу з'ясувати, хай і приблизно, в якому напрямі еволюціонує світ і які можливі наслідки людської поведінки для цієї еволюції» [4, 134].

У зв'язку з цим зазначимо, що осмислення специфіки відображення проблематики «СхідЗахід» у творах музичного мистецтва час до часу фігурує у працях музикознавчого спрямування. Головним чином, ретельному дослідженню піддаються механізми когнітивних процедур, що притаманні східному і західному стилям художньо-музичного мислення (зазвичай у контексті їх розрізнення як полярних типів). Також, розглядаються пов'язані з цим змістові аспекти організації музичної матерії (згадаємо, приміром, наукові праці О. Алкон [1]). Паралельно здійснюється детальне музикознавче вивчення семантики конструктивних елементів музичної мови - мелодики, гармонії, 
тембру, динаміки, регістровки, ритміки, фактури тощо у контексті виокремлення відмінних ознак мови і мовлення західного та східного зразка їх системно-структурної організації (Г. Завгородня [9]).

Відтак, при комплексному опануванні властивостей та своєрідності мовно-інтонаційних моделей східної та західної музичних культур, що знаходять своє безпосереднє виявлення у творчості видатних композиторів i виконавців, дедалі частіше набуває актуалізації потенціал філософії музичного аналізу (А. Кравченко [5]). Це поступово виводить музикознавство на новий якісний рівень філософсько-культурологічних узагальнень, що наближає до розуміння фундаментальних підоснов та окреслення перспектив музичної культурології як міждисциплінарної галузі наукового знання, яка перебуває на стадії кристалізації свого теоретико-методологічного інструментарію.

Разом 3 тим підкреслимо, що попри музикознавче осягнення техніко-композиційних особливостей творення інтонаційно забарвлених у східній чи західній стилістиці звукових комплексів, окреслена проблематика досі не отримала належного висвітлення зі світоглядних позицій музичної культурології. Останнє передбачає синтезування концептуальних настанов культурології і музикознавства у поглибленому опануванні, з одного боку, цивілізаційних засад східної та західної культур, а $з$ іншого - «інтонаційного образу світу» (Ю. Чекан) цих культур, що конденсується в музичних композиціях у конкретних звукових образах.

Метою статті є дослідження специфіки моделювання звукообразів світової гармонії у філософсько-культурологічних аспектах репрезентації проблематики Схід-Захід у музичній культурі.

Виклад основного матеріалу. Протягом останніх десятиліть спостерігаємо неабиякий інтерес до побудови культурологічних концепцій глобально-цивілізаційних засад світової культури. Зокрема й тих, що окреслюють ієрархічні вісі «центр - напівпериферія - периферія», визначаючи культурноісторичний статус різних регіонів світу у ході трансформаційної мінливості процесів культурогенезу. Серед них, увиразнюються праці, де аналізуються тенденції балансу/дисбалансу, поліпшення / загострення історичних, економічних, військово-політичних, соціальних релігійних, культурно-мистецьких відносин і протиріч між Заходом і Сходом - цивілізаціями, які «незважаючи на багатовікову історію взаємин, $<\ldots>$ так і не подолали світоглядного паралелізму і залишаються антиномними системами» $[3,4]$.

На думку багатьох авторитетних вчених, коріння цих та інших фундаментальних розбіжностей криється у психологічних особливостях східного та західного менталітету i темпераменту, як інтраверсійного та екстраверсійного за своїм типом. «Інтроверсія, якщо можна так висловитися, $\epsilon$ "стилем" Сходу, звичною та колективною установкою, так само як екстраверсія $\epsilon$ "стилем" Заходу», пише К. Г. Юнг [8, 234]. Це пояснює альтернативність, антитетичність культурносвітоглядних позицій та наявних проблем міжкультурної взаємодії, що подекуди набувають загострення в умовах глобалізації. Західна культура зазвичай асоціюється з раціональною свідомістю, впровадженням науково-технічних інновацій, культивуванням демократичних цінностей, громадянських прав і свобод, а східна, навпаки, - сприймається як така, що орієнтована на колективно-общинні пріоритети, традиційний міфо-релігійний досвід, інтуїтивізм та спіритуалізм світовідчуття, пошуки світової гармонії тощо.

Незважаючи на постульовану дихотомію східних та західних культурно-історичних традицій, на сучасному етапі відбувається інтенсифікація міжкультурної комунікації в полінаціональному культурному середовищі. Під дією глобалізаційних процесів у культурі «миттєва уседосяжність та загальнодоступність інформаційних потоків спричиняє поступове усталення незнаних досі культурним традиціям явищ синхронізації культуротворчих процесів, конвергенції та наступу тотального уніформізму» [7, 6-7]. Безпосередньо це стосується й європейської музичної культури, де співпричетність до вільного діалогу культур та супутня мобільність інтернаціоналізації художнього мислення $є$ потужним креативним ресурсом художньо-музичної творчості.

У зв'язку з цим постають питання, яким чином цивілізаційні засади східної та західної культур екстраполюються на мову музичного мистецтва? А також, у якій семантичній якості перекодована у відповідний техніко-композиційний спосіб культурна інформація постає у новому мовно-знаковому контексті?

Аналізуючи у цьому ракурсі мистецький доробок європейських композиторів XX - початку XXI століть, зокрема i українських, спостерігаємо інтенсифікацію процесів «імпорту» деяких образно-тематичних концепцій та мовно-інтонаційного «словника» музики неспоріднених культур східного ареалу з подальшим їх творчим переосмисленням-асиміляцією. У результаті це веде до створення оригінального художньо-мистецького продукту інтелектуальної творчості, що привертає увагу аудиторії та, водночас, поволі розширює горизонти місцевих музичних традицій і смаків, збагачуючи слуховий досвід реципієнтів. 
Так, у творах європейського музичного мистецтва проблематика «Схід-Захід» знаходить відбиття у конкретних звукообразах, кожен з яких, з точки зору музичної культурології, постає «смисловою моделлю, яка інтегрує (узагальнює) фонологічне (звуковисотне, темброве, ритмічне, динамічне), образно-інтонаційне (інтонаційне, ладове, метричне, гармонійне), логіко-конструктивне (фактурне, синтаксичне, жанрово-семантичне) мислення на вищому - звукосимволічному - рівні художнього цілого як художньо-змістовий концепт» $[6,185]$.

При цьому необхідною умовою моделювання подібних звукообразів виступає свідоме або несвідоме закладання відповідних культурних кодів - міфологічних, фольклорних, релігійних. Насамперед, це пов'язано не тільки 3 «процесом встановлення семіотичних, семантичних, асоціативних, психологічних зв'язків між різними кодомовними системами музичного, хореографічного та образотворчого видів мистецтва» $[2,286]$, а й 3 тією роллю «провідника» етнонаціональної характерності, що виконують культурні коди, надаючи музиці бажаного семантикосеміотичного колориту (стилістичного, мелодико-гармонійного, ритмічного, ідейно-образного та ін.).

Впродовж XX та на початку XXI століть мовно-інтонаційна специфіка музики західної культурної традиції набуває все більш експериментально-інноваційних рис (радикальне оновлення музичної мови, бурхливий розвиток мистецьких технологій, впровадження розмаїття аудіовізуальних видовищних форм художньо-музичного висловлювання тощо). Останне напряму пов'язане 3 раціоналізмом, лібералізмом та «відкритістю» західного мислення, що віддзеркалює звуковий еталон культури окресленого історичного періоду. Згадаємо, приміром, музичну творчість французьких урбаністів (Артюр Онегтер «Пасіфік-231»), серіалістів дармштадської школи (Карлхайнц Хтокхаузен «Мікстура»), українських авангардистів-шістдесятників (Леонід Грабовський «Мікроструктури») та iн.

Натомість, уявлення європейських композиторів про культуру Сходу, зазвичай, передається за допомоги художніх прийомів цитації, алюзії, ремінісценції, квазі-/ нео-фольклорної стилізації східних ритмо- та мелодико-гармонійних формул. Вони викликають стійкі відчуття орієнталізму в музиці, асоціативно відсилаючи до тих чи інших ладо-інтонаційних архетипів індійської, японської, китайської, арабської музичних культур [див.: 1]. Серед прикладів, наведемо такі твори іноземних та українських композиторів, як: «Morgen-Raga» Рауля де Смета, «Рубайят» Софії Губайдуліної, «Симург-квінтет» Вікторії Польової, «3 японської поезії» Сергія Пілютикова та ін, де опосередковано передається авторське відчуття східної культури - уповільненого плину часу, медитативного споглядання, сакрального пошуку «гармонії зі світом, що несе спокій людині, яка є часткою природи» $[9,285]$ тощо.

Нерідко в творах європейських композиторів зустрічаємо й такі ідейно-програмні й семіотичні конфігурації, де переплетення західних та східних культурних кодів в образності та музичній стилістиці відбувається в межах однієї композиції (наприклад, Арво Пярт «Orient and Occident», Світлана Азарова «East-West»). Тут найчастіше перетинаються два протилежних типи художньо-музичного мислення - континуальне та дискретне, відтак звукообрази витонченого, духовно-просвітленого, медитатуючого Сходу протиставляються звукообразам жорсткого, урбаністичного, технократичного Заходу.

Водночас сучасні концепції музичних композицій презентують не тільки антагоністичне віддалення неспоріднених культурних традицій Сходу і Заходу, але й констатують їх нерозривну першоджерельну єдність. У цьому контексті була докладно проаналізована творчість композиторів української школи, яка «протягом останнього півстоліття вельми різноаспектно розкривається у вимірах своєї еволюції від натурфілософського, піфагорійського розуміння музичної образності та структури до філософії медитації, відображення світоглядних систем Сходу та озвучених платонівських ідей у музиці» $[5,48]$.

Яскравим прикладом тут слугує творчість Валентина Сильвестрова, який відмовившись від популярної нині постмодерної техніки музичного письма і застосовуючи в останні роки виключно мовно-інтонаційну палітру європейської класики, культивує саме ті образи, що увиразнюють непомітні, на перший погляд, зв'язки двох культур. Останнє виявляється у інтровертивній заглибленості музики Валентина Сильвестрова, прагненні до пошуку внутрішньої і зовнішньої гармонії, спокою і духовної тиші, естетичного споглядання вічного і прекрасного у неквапливому розгортанні музичного часу і простору («Post Scriptum», «Багателі», «Метамузика»). Все це втілює в музиці ті ідеї світової гармонії, які проявляються, здебільшого, крізь призму звукообразів тиші та $\epsilon$ одночасно близькими як східним, так і західним світоглядним настановам і духовним прагненням. Тим самим, Валентин Сильвестров постулює не дихотомію, а дуалізм культур Сходу і Заходу у нерозривному, глибинному взаємозв'язку їх традицій. 
Наукова новизна. Тож, проведене дослідження специфіки моделювання звукообразів світової гармонії у філософсько-культурологічних аспектах віддзеркалення проблематики «Схід-Захід» у музичній культурі дозволило, з одного боку, увиразнити конкретні змістові та мовно-виражальні напрями репрезентації звукообразів культур східного та західного цивілізаційного типу, а з іншого боку, констатувати доцентрові тенденції інтерпретації мовно-інтонаційного образу світу - від дихотомії до дуалізму східної та західної культур крізь призму відображення звукообразу тиші як художньо-музичного уособлення світової гармонії.

Висновки. У підсумку зазначимо, що сучасні глобально-цивілізаційні виклики актуалізують проблематику діалогу східної ї західної культур (азійського та європейського, північноамериканського ареалу). 3 одного боку, загострюються культурні протиріччя, а 3 іншого, пришвидшуються потоки міжкультурної комунікації за лініями східно-західного партнерства. Ці процеси знаходять безпосереднє виявлення в європейській музичній культурі, де філософськокультурологічна специфіка репрезентації діалогової вісі «Схід-Захід» знаходить відображення у звукообразах як «художньо-змістових концептах», що віддзеркалюють вектори протиставлення, віддалення, наближення та дуалізму культур. Останнє, виражається у звукообразах тиші, моделювання яких відповідає світоглядній парадигмі східного та західного мислення, уособлюючи ідеальний звуковий образ світової гармонії, що в умовах постмодерної парадигми $є$ точкою культурного зближення двох антиномних світів.

\section{Jimepamypa}

1. Алкон Е. М. Континуальное и дискретное в музыкальном мышлении Востока и Запада. Взаимодействие художественных культур Востока и Запада. М.: Государственный институт искусствознания, 1998. C. 112-133. 2017. $314 \mathrm{c}$.

2. Афоніна О. С. Коди культури і «подвійне кодування» в мистецтві : монографія. Київ : НАКККіМ,

3. Герчанівська П. Е. Дихотомія Схід-Захід: історико-культурологічний аспект. Вісник Національної академії керівних кадрів культури і мистецтв : наук. журнал. Київ: ІДЕЯ-ПРИНТ, 2019. № 1. С. 3-8.

4. Гуменюк Т. С., Тишко С. В. Музична культурологія в координатах гуманітарного мислення. Часопис Національної музичної академії України імені П. І. Чайковського. 2018. № 1 (38). С. 128-139.

5. Кравченко А. І. Філософська проблематика музичного мислення українських композиторів (від авангарду 60-х до сучасності). Вітчизняна наука на зламі епох: проблеми та перспективи розвитку : зб. наук. праць XXI Всеукр. наук.-практ. інтернет-конф., 5-6 березня, 2016 р. Переяслав-Хмельницький : Державний вищий навчальний заклад «Переяслав-Хмельницький державний педагогічний університет імені Григорія Сковороди», 2016. С. 46-48.

6. Рябуха Н. О. Звукообраз як категорія музичного мислення: онтологічний та гносеологічний аспекти. Міжнародний вісник: культурологія, філологія, музикознавство : наук. журнал. 2015. Вип. II (5). С. $181-187$.

7. Сюта Б. Глобалізаційні та периферизаційні процеси в культурі як чинник організації художньої цілісності в сучасній музиці : дослідження. Сер. «Музика вчора, сьогодні і завтра». Кн. 2. Київ : УБСП «Комора», 2006. 65 c.

8. Юнг К. Г. Различие между восточным и западным мышлением. О психологии восточных религий и философий / Сост. В. Бакусев. М. : «МЕДИУМ», 1994. 258 c. URL: http://www.nhatnam.ru/biblio/yung/vostok_i_zapad.html (дата звернення: 28.04.2019).

9. Zavgorodnyaya G. Semantics of musical language elements as an indicator of differences of Western and Eastern thinking. Music arts and culture, 2014. № 20. P. 283-294.

\section{References}

1. Alkon E. M. (1998). Continual and discrete in the musical thinking of the East and the West. The interaction of artistic cultures of the East and West. Moscow: State Institute of Art Studies, pp. 112-133 [in Russian].

2. Afonina O. S. (2017). Codes of culture and «double coding» in art. Kyiv: NAKKKiM [in Ukrainian].

3. Gerchanovskaya P. E. (2019). Dichotomy East-West: Historical-Cultural Aspect. Herald of the National Academy of Managerial Staff of Culture and Arts: quarterly journal, 1, 3-8 [in Ukrainian].

4. Gumenyuk T. S., Tyshko S. V. (2018). Musical cultural studies in the coordinates of humanitarian thinking. A journal of the P. Tchaikovsky National Music Academy of Ukraine, 1 (38). 128-139 [in Ukrainian].

5. Kravchenko A. I. (2016). Philosophical problems of musical thinking of Ukrainian composers (from the avant-garde of the 60's to the present). Proceeding from XXI All Ukraine scientific and practical conference «Ukrainian science at the turn of the epoch: problems and prospects of development». (pp. 46-48). Pereyaslav-Khmelnytsky: State Higher Educational Institution «Pereyaslav-Khmelnytsky State Pedagogical University named after Gregory Skovoroda» [in Ukrainian].

6. Ryabukha N.O. (2015). Sound as a category of musical thinking: ontological and epistemological aspects. International Bulletin: Culturology, Philology, Musicology: scientific journal, II (5). 181-187 [in Ukrainian]. 
7. Siuta B. (2006). Globalization and peripheral processes in culture as a factor in the organization of artistic integrity in contemporary music: Kn. 2. Kyiv: UBSP «Komora» [in Ukrainian].

8. Jung K. G. (1994). The Difference Between Oriental and Western Thinking. About the Psychology of Eastern Religions and Philosophy. Retrieved from http://www.nhat-nam.ru/biblio/yung/vostok_i_zapad.html

9. Zavgorodnyaya G. (2014). Semantics of musical language elements as an indicator of differences of Western and Eastern thinking. Music arts and culture, 20, 283-294 [in English].

Стаття надійшла до редакиї 24.01.2019 p.

УДК 012+(911.375.1:130.2)

\author{
Боголюбова Ірина Владиславівна, \\ аспірантка Національної академії \\ керівних кадрів культури і мистецтв \\ ORCID 0000-0002-1154-122X \\ avena9@outlook.com
}

\title{
УРБАНІСТИЧНА КУЛЬТУРОЛОГІЯ: ПОЧУТИ ОБРАЗ МІСТА (ЧАСТИНА І)
}

Мета роботи полягає у розробці бінарної системи образу міста: колективне-індивідуальне й конкретнеабстрактне. Визначенні особливостей дослідження образу міста через призму саундскейпу. Узагальненні сучасного світового досвіду репрезентації результатів застосування саундскейпу в культурних практиках. В даній розвідці задіяно структурно-функціональний, термінологічний методи, інтерв'ю, контент-аналіз, метод моделювання. Наукова новизна полягає у вперше проведеному в українській культурологічній думці дослідженні методу саундскейпу й інтерпретації феномену образу міста в аудіо композиціях, створених на основі філд-рекордінгу. Висновки. Через призму саундскейпу науковці спроможні зафіксувати динаміку змін як міста, так і його соціокультурного простору; трансформації в його «житті» і розвитку, виділити проблемні зони, інволюцію соціокультурних субзон. Підкреслюємо, що саундскейп має перевагу в дослідженні образу міста через те, що прослуховування звукового ландшафту надає головну інформацію - достеменно вести оповідь безпосередньо знаходячись на місці.

Ключові слова: саундскейп, філд-рекордінг, звуковий ландшафт, образ міста, міське середовище, місто.

\section{Боголюбова Ирина Владиславовна, аспирантка Нацииональной академии руководящих кадров культуры и искусств \\ Урбанистическая культурология: услышать образ города}

Цель работы является в разработке бинарной системы образа города: коллективное-индивидуальное и конкретное-абстрактное. Определении особенностей исследования образа города через призму саундскейпа. Обобщении мирового опыта репрезентации результатов применения саундскейпа в культурных практиках. В данной разработке задействованы структурно-функциональный, терминологический методы, интервью, контент-анализ, метод моделирования. Научная новизна заключается в впервые проведенном в украинской культурологической мысли исследования метода саундскейпа, а также интерпретации феномена образа города в аудио композициях, созданных на основе филд-рекординга. Выводы. Через призму саундскейпа исследователи способны зафиксировать динамику изменений как города, так и его социокультурного пространства; трансформации в его «жизни» и развитии, выделить проблемные зоны, инволюцию субкультурных зон. Подчеркиваем, саундскейп имеет приоритет в исследовании образа города, поскольку прослушивание звукового ландшафта предоставляет главную информацию - истинно вести описание непосредственно находясь на месте.

Ключевые слова: саундскейп, филд-рекординг, звуковой ландшафт, образ города, городское пространство, город.

\section{Boholiubova Iryna, Graduate student, National Academy of Culture and Arts \\ Urban Cultural Studies: to hear the image of the city}

The purpose of the article is to develop a binary system of the image of the city: collective-individual and concrete-abstract. Determining the features of the study of the image of the city through the prism of the soundscape. Generalization of the world experience of representation of the results of soundscape application in cultural practices. Methodology. This development involves structural and functional, terminological methods, interviews, content analysis, modeling method. Scientific novelty lies in the research of the soundscape method for the first time in Ukrainian cultural thought, as well as in the interpretation of the phenomenon of the image of the city in audio compositions created on the basis of field-recording. Conclusions. Through the prism of the soundscape, researchers are able to record the dynamics of changes in both the city and its socio-cultural space; transformation in its "life" and

(C) Боголюбова I. В., 2019 